\section{Science in the Himalayas}

\author{
Peter D. Moore, recently in India, finds
} some scientific surprises in the mountains

NYONE who travels in India soon
grows accustomed to the un-
expected. Even so, the little town of
Dehra Dun, nestling in the foothills of
the Himalayas ten hours' train journey
north of Delhi, will surprise the most
hardened traveller, for it occupies an
influential position in Indian science.
It serves as a centre for research,
training and exploration in such in-
dustries as oil and natural gas and in
forestry, and it is also the base for the
Northern Region of the Botanical
Survey of India. The most unexpected of these is perhaps the oil industry, especially when one considers the distribution of oil and natural gas exploitation in India. At present there are two major sedimentary basins yielding oil (see accompanying map), located at the eastern and western extremities of the subcontinent. In the east is the AssamArakan basin, which is being exploited by both the Indian Oil and Natural Gas Commission (ONGC) and by Oil India Ltd, in which the Indian Government and the British Burma Oil Company hold equal shares. At present Oil India is producing $3.08 \times 10^{6}$ tons annually from Assam, representing more than a third of India's total oil production. Further development of this field could double its output. In the west of India, in Gurarat, is the Cambay Basin, which extends from the coast to the gas-bearing strata of Rajasthan and south into the Gulf of Cambay. This field was discovered in the late 1950s and since then the offshore fields of the Bombay High have also been brought into production.

Crude oil production has risen from 259,000 tons a year in 1951 to a present output of about $8 \times 10^{6}$ tons. Greatest expansion was achieved between 1963 and 1969. At the same time annual consumption of petroleum products has risen from $3.9 \times 10^{6}$ tons in 1951 to a present level of about $23 \times 10^{6}$ tons. India is thus producing only one third of her oil needs.

Oil consumption in India will undoubtedly continue to grow. Apart from her fuel requirements, the growth of the petrochemical and fertiliser industries will present an increasing demand. There is already talk of lining canals with polythene to prevent water losses, and even the possibility of covering whole fields. In fishing, clothing and domestic construction, particularly in the improvement of water supplies and sewerage, plastic products will contribute to efficiency and to health. Historically, many apparently profound influences have been passively absorbed by India and have been swallowed by the inertia of her ageless culture, leaving her unchanged. Will plastics really alter the face of India? One wonders whether the Indian's concern for the welfare of bovines will actually result in a plastic bullock cart fitted with pneumatic tyres - a suggestion recently made by Dr S. Varadarajan, Chairman of Indian Petrochemicals Ltd.

\section{Growing demand}

On the fertiliser side, the current production of about $1.5 \times 10^{6}$ tons of nitrogen has placed a growing demand upon crude oil. Many plants consume sulphur-rich fuel oil, which can be imported relatively cheaply because of the air pollution resulting from $\mathrm{SO}_{2}$ production on combustion and because of the strength of the ecological lobby in the industrialised nations. India, like so many developing nations, does not yet feel in a position to afford the clean air which the developed nations now vainly seek.

What India also cannot afford is that its oil import bill should continue to rise. Great emphasis is now placed, therefore, upon the closure of the gap between home production and consumption of petroleum products. Optimistic predictions abound in India at present. Prospects for the development of existing fields, particularly the offshore drilling in the Bombay High, are good. Proven reserves on land in India are estimated at $700 \times 10^{6}$ tons, of which $200 \times 10^{6}$ tons are considered recoverable, while the Bombay High is thought to contain at least another $800 \times 10^{6}$ tons. N. B. Prasad. chairman of ONGC, considers that production from these maior fields can rise to about $20 \times 10^{6}$ tons a year within the next four years, thus narrowing very considerably the gap between production and demand in the country.

The nolitical dream of an India selfsunportins, in her oil needs, however. still demands further exploration and develonment. This is where the Himalavan town of Dehra Dun comes into the nicture. In 1963 an Institute of Petroleum Exnloration was set un with the aid of money from the United Nations Develonment Programme. The annarently strange choice of site falmost equally distant from both of the major oil producing areas) can be

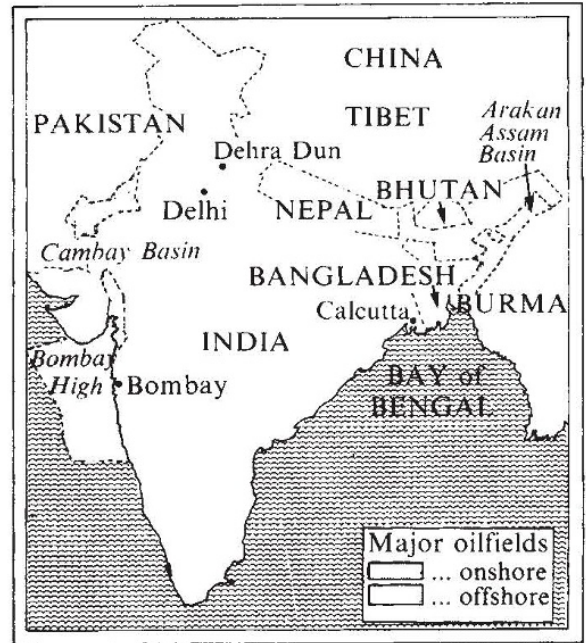

explained by the contemporary search for oil in the Himalaya foothills. In the fourteen years since the inception of this institute no reserves of a commercially viable nature have yet been discovered, thus leaving it stranded in a remote but scenic location which was once the summer playground of the British Raj.

Exploration and analytical research remain the prime functions of the Dehra Dun Institute. A comprehensive evaluation of the sedimentary basins of India is under way, no mean task given that it covers basin areas of $10^{6}$ $\mathrm{km}^{2}$ onshore and $320,000 \mathrm{~km}^{2}$ offshore. The volume of chemical, geological and palynological data generated in the laboratories at Dehra Dun has necessitated the installation of an IBM 370/ 145 computer in the institute for rapid assessment of oil-bearing potential. Russian influence at the Institute has been and remains strong. The original UN representative at the establishment of the institute was a Russian and a team of scientists from the Soviet Union assists in research and analysis.

\section{Forestry too}

The Institute of Petroleum Exploration is not the only surprise awaiting the visitor to Dehra Dun. Just $6 \mathrm{~km}$ west of the town stands a most extraordinary and impressive building set in 445 ha of lawns and gardens. It houses the Indian Forest Research Institute. Built in 1929 and inaugurated by the then Viceroy of India, Lord Irwin, this institute is a monument to the economic importance of forestry in India. It began as the Imperial Forest School in 1884 and then expanded to encompass forest research. It now serves both a research and teaching function and houses a staff of 1,900 .

As in many other countries. India has suffered badly from deforestation and the resultant soil erosion. This has reoutedly come about particularly since Moghul times in north India. It is said 
(usually by Hindus) that the Mohammedans did not possess the same respect for vegetation as their Hindu predecessors. It is certainly true that vast areas of the Himalayan foothills have been stripped of forest and now only fragments remain. This has come about both as a result of intensive grazing and also the use of wood for fuel.

The varied topography in the region of Dehra Dun provides an ideal setting for a Forestry Institute. The steep slopes of the Lesser Himalayas take one up out of the sub-tropical climate of the plains and the Siwalik Hills into the cool temperate climate of the foothill ridges. Broad features of forest zonation accompany these altitude changes. It is thus possible for students at the Forest Research Institute to gain experience in a variety of forest conditions.

Besides the practical aspects of silviculture, the institute offers training and research facilities in such fields as entomology, paper technology, wood physics, timber mechanics and genetics. The main buildings house a vast museum and herbarium. The institute has served an important function in the development of techniques suitable for the conditions found in India. For example, the use of bamboo as a raw material in the manufacture of paper was pioneered here, as was the use of sugar cane waste. Bamboo, the poor man's timber and the standard material for scaffolding in India, represents a jungle to the taxonomist. There are about a hundred species and they flower only once, immediately prior to death, so that by the time you can identify them it is too late. Techniques for identification on the basis of culm sheaths and young bud structure are currently being worked upon, since identification is essential for the further development of bamboo management methods.

Besides the obvious products of forestry, timber and pulp, the Indian forests are rich in species which are economically important as a source of minor products. For example, the oil from sandalwood is an important earner of foreign exchange for India. The production of santonin from certain Artemisia species is an area which has recently received attention. The survey of Indian plants for potentially useful species is thus of considerable importance. The Forest Research Institute deals with woody plants, but what of the others?

\section{Botanical survey}

It comes as no surprise to find yet another institute tucked away in the suburbs of Dehra Dun, this time the headquarters of the Northern Circle of the Botanical Survey of India. This is a government organisation which is centred on Calcutta and which functions through four Regional Circles. The emphasis is upon plants as a national resource (in an economic rather than an aesthetic sense), but the bulk of the work is purely taxonomic. At present the flora of India has still not been fully described and the high Himalayas represent a particularly underworked area.

Because a major aim of the survey is the discovery of plants with a commercial potential, especially those with medicinal properties, the development of a herbarium of dried specimens is not enough; plants must be kept alive. The establishment of a botanical garden is therefore a priority and, as many of the more interesting plants derive from high altitude, the garden must also be sited in the hills. The British developed an upland botanic garden at Mussoorie (about 2,200 m) but this has now been abandoned as a scientific venture. A new garden has been estab- lished at Pauri $(1,500 \mathrm{~m})$ which will be used to maintain populations of high altitude plants and for experimentation. Such a venture may also prove to be valuable for the conservation of some rarer species, such as some of the orchids, and may also provide material for horticultural developments.

Perhaps the plant resources of the Himalayas will soon provide the basis for further commercial exploitation in the form of tourism. It still takes a considerable muscular effort to reach the Bhyundhar Valley (the "Valley of Flowers') at $3,600 \mathrm{~m}$ but one can envisage changes coming about as India seeks more opportunities to earn foreign exchange. Although the Hindu pilgrims are prepared to trek on foot to their mountain shrines, the Western tourist will undoubtedly demand the development and despoilation of these remote areas. Conservatism, a right sense of priorities, or even sheer inertia may make India unwilling to pay the price.

Diagrammatic section of the Western Himalayas

showing major forest types

(Data derived from Botanical Survey of India)
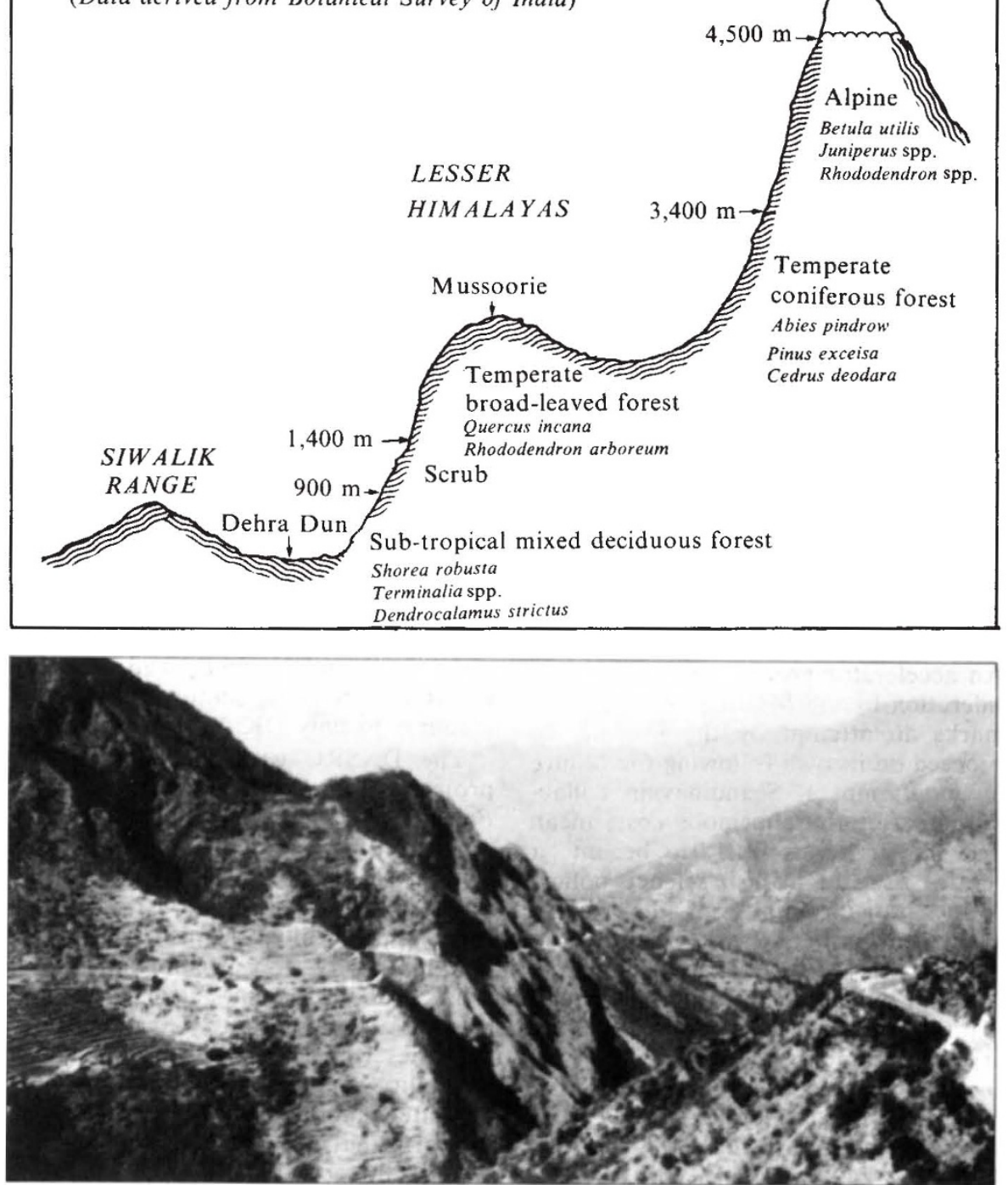

Cultivated terraces near Mussoorie in the Himalayas

$H I G H$

HIMALAYAS

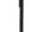

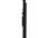

